\title{
ARTIGO
}

CO https://doi.org/10.22481/praxisedu.v15i36.5936

\section{THE DEVELOPMENT OF COMMUNICATIVE COMPETENCE OF UNIVERSITY STUDENTS IN THE PROCESS OF THEIR PROFESSIONAL TRAINING}

\author{
EL DESARROLLO DE LA COMPETENCIA COMUNICATIVA DE LOS ESTUDIANTES \\ UNIVERSITARIOS EN EL PROCESO DE SU FORMACIÓN PROFESIONAL \\ O DESENVOLVIMENTO DA COMPETÊNCIA COMUNICATIVA DE ESTUDANTES \\ UNIVERSITÁRIOS NO PROCESSO DE SUA FORMAÇÃO PROFISSIONAL
}

Olga L. Nazarova

Nosov Magnitogorsk State Technical University, Magnitogorsk - Russia

Svetlana V. Rudakova

Nosov Magnitogorsk State Technical University, Magnitogorsk - Russia

Tatiana V. Akasheva

Nosov Magnitogorsk State Technical University, Magnitogorsk - Russia

Svetlana S. Velikanova

Nosov Magnitogorsk State Technical University, Magnitogorsk - Russia

Anastasiia A. Bakholskaia

Nosov Magnitogorsk State Technical University, Magnitogorsk - Russia

Oksana P. Chernykh

Moscow University of Finance and Law MFUA, Moscow - Russia

\begin{abstract}
The presented article is devoted to the development of communicative competence of students of higher educational institutions in the process of their professional training. Based on the works of such researchers as B.G. Ananiev, A.A. Bodalev, V.A. Kan-Kalik, E.D. Bozhovich, L.A. Petrovskaya, I.A. Zimnyaya, etc., the authors defined more exactly the content of the concept "communicative competence of students of a higher educational institution", systematized its criteria and indicators (Bakholskaya, 2017; Bakholskaya, 2019; Bakholskaya, 2018; Bakholskaya, 2019; Zimnyaya, 2003). The article also presents the authors complex of pedagogical conditions, which ensure the development of communicative competence of university students in the process of their professional training. The complex includes the
\end{abstract}


following components: involvement of students in an intensive educational communicative environment; creation of communicative situations on the basis of educational (professional) problems, ensuring the formation of students' communicative competence; organization of various types of group interaction between the teacher and students, based on the application of interactive methods, techniques and technologies. The article also presents the results of experimental work, which has confirmed the effectiveness of the developed complex of pedagogical conditions, ensuring the development of students' communicative competence in the process of their professional training.

Keywords: communicative competence, professional training of students.

Resumen: El artículo presentado está dedicado al desarrollo de la competencia comunicativa de los estudiantes de instituciones de educación superior en el proceso de su formación profesional.

Basado en los trabajos de investigadores como B.G. Ananiev, A.A. Bodalev, V.A. Kan-Kalik, E.D. Bozhovich, L.A. Petrovskaya, I.A. Zimnyaya, etc., los autores definieron más exactamente el contenido del concepto "competencia comunicativa de los estudiantes de una institución de educación superior", sistematizaron sus criterios e indicadores (Bakholskaya, 2017; Bakholskaya, 2019; Bakholskaya, 2018; Bakholskaya, 2019; Zimnyaya , 2003). El artículo también presenta a los autores un complejo de condiciones pedagógicas, que aseguran el desarrollo de la competencia comunicativa de los estudiantes universitarios en el proceso de su formación profesional. El complejo incluye los siguientes componentes: participación de los estudiantes en un ambiente educativo comunicativo intensivo; creación de situaciones comunicativas sobre la base de problemas educativos (profesionales), asegurando la formación de la competencia comunicativa de los estudiantes; Organización de varios tipos de interacción grupal entre el profesor y los alumnos, basados en la aplicación de métodos, técnicas y tecnologías interactivas. El artículo también presenta los resultados del trabajo experimental, que ha confirmado la efectividad del complejo desarrollado de condiciones pedagógicas, asegurando el desarrollo de la competencia comunicativa de los estudiantes en el proceso de su formación profesional.

Palabras clave: competencia comunicativa, formación profesional de los alumnos.

Resumo: O artigo apresentado é dedicado ao desenvolvimento da competência comunicativa de estudantes de instituições de ensino superior no processo de formação profissional. Com base nos trabalhos de pesquisadores como B.G. Ananiev, A.A. Bodalev, V.A. Kan-Kalik, E.D. Bozhovich, L.A. Petrovskaya, I.A. Zimnyaya, etc., os autores definiram mais exatamente o conteúdo do conceito "competência comunicativa de alunos de uma instituição de ensino superior", sistematizaram seus critérios e indicadores (Bakholskaya, 2017; Bakholskaya, 2019; Bakholskaya, 2018; Bakholskaya, 2019; Zimnyaya 2003). O artigo também apresenta aos autores um complexo de condições pedagógicas, que garantem o desenvolvimento da competência comunicativa de estudantes universitários no processo de formação profissional. O complexo inclui os seguintes componentes: envolvimento dos alunos em um ambiente comunicativo educacional intensivo; criação de situações comunicativas com base em problemas educacionais (profissionais), garantindo a formação da competência comunicativa dos alunos; organização de vários tipos de interação em grupo entre professor e alunos, com base na aplicação de métodos, técnicas e tecnologias interativas. O artigo também apresenta os 
resultados do trabalho experimental, que confirmou a efetividade do complexo desenvolvido de condições pedagógicas, garantindo o desenvolvimento da competência comunicativa dos alunos no processo de formação profissional.

Palavras-chave: competência comunicativa, formação profissional de estudantes.

\section{Introduction}

\section{Introduction to the problem}

Among all human activities, professional activity takes a special place. The issues of communication, interaction, mutual understanding, cooperation and dialogue between people are extremely acute and significant in this activity. The researches of specialists' training in Russian universities and the further professional activities of graduates (V.M. Aleksandrov, S.A. Kugel, V.P. Kuzovlev, V.V. Loginov, B.F. Lomov, A.V. Filippov, etc.) showed the following results: communicative abilities and skills are the most significant in the general system of professionally important qualities of a modern specialist; the effectiveness of a specialist's work to the greatest extent depends on the nature of his relations with colleagues; among the various difficulties and problems, arising in professional activities, one of the first places is occupied by communicative difficulties and communication problems; the greatest dissatisfaction of society and the workers is caused by those aspects of their professional training, which are related to the style of communication, skills of interpersonal interaction, cooperation and dialogue with partners; in pedagogical science, the conditions and methodology for the formation of communicative competence of university students, based on the application of interactive methods, techniques and technologies, remain understudied (Goncharov, 2004; Dvulichanskaya, 2011; Koroleva \& Kosterina, 2015).

\section{The relevance of the problem}

The relevance of the problem of development of communicative competence of university students in the process of their professional training is determined by the following factors: 
- modernization of higher education, due to the change in the paradigm of development of higher education, and the need to improve the quality of education;

- the increased demand of the labor market for the specialists, who are able to quickly adapt to changing conditions, due to the high level of communicative competence;

- the need for motivational support for the development of communicative competence of modern students. A person who is capable of cooperation and dialogue with people, who knows how to build relationships on the principles of humanism, democracy, equality, trust and openness - is ready for competitive relationships and for the self-education throughout his professional career (Serikov, 1994; Khayrullov, 2005; Korthagen et al, 1999; Nazarova et al, 2018).

\section{Problem study}

Communicative competence as a scientific concept in psychological and pedagogical literature is still not defined in terms of its significance for professional pedagogy. The authors of the article believe that the reasons for this are the lack of unambiguous understanding of this term, and its specificity with respect to professions, which belong to the sphere of increased speech responsibility.

The analysis of existing interpretations of communicative competence shows that this is an interdisciplinary term (B.G. Ananiev, A.A. Bodalev, Yu.A. Eljanov, O.A. Kotsanskaya, V.A. Kan-Kalik and others). The issues of the formation of communicative competence were investigated in the works of E.D. Bozhovich, E.A. Bystrova, E.M. Vereshchagina, N.I. Gimpel, I.A. Zimnyaya, I.A. Kolesnikova, V.G. Kostomarova, A.A. Leonov, L.A. Petrovskaya, E.I. Passov et al. The problems of the formation of communicative competence in the process of students training are considered in the works of R.A. Agakhanova, E.D. Alisultanova, I.D. Belonovskaya et al. The analysis of theoretical sources shows that the components of communicative competence of students of higher educational institutions are being actively studied today. A number of researchers (V.A. Labunskaya, E.V. Rudenskiy, and others) emphasize the cognitive component of this phenomenon; A.V. Zakharov, A.V. Mudrik, I.A. Zimnyaya describe the structure of communicative competence through the communicative skills; communicative knowledge and skills (E.V. Sidorenko) and personal characteristics (L.I. Berestova, Yu.N. Emelyanov, L.A. Petrovskaya, E.V. Semenov, etc.) are the structural 
components of communicative competence (Zimnyaya, 2003; Ardashkin et al, 2015; Arokiasamy et al, 2013; Shure, 1981; Soldatchenko \& Kostyuchenko, 2017).

However, despite the extensive analysis of the phenomenon of communicative competence in scientific literature, its practical aspects, in particular, the formation of communicative competence of students in higher educational institution is understudied. The noted circumstance determined the choice of the topic of presented article.

\section{Hypothesis}

The development of communicative competence of university students will be effective in case of implementation of the following complex of pedagogical conditions:

1. The involvement of students in an intensive educational communicative environment.

2. Creation of communicative situations on the basis of educational (professional) problems, ensuring the formation of students' communicative competence.

3. Organization of various types of group interaction between the teacher and students, based on the application of interactive methods, techniques and technologies.

\section{Methods}

In order to achieve the objectives, we used the complex of theoretical and empirical methods of the research: theoretical and comparative analysis of literature on the investigated problem, the analysis of regulatory framework of higher educational institutions, targeted pedagogical observation, questionnaires, testing of students and teachers, modeling of sociopedagogical situations in the educational process; generalization of experimental data, their analytical and mathematical processing.

\section{The Main Part}

Addressing the problem of development of students' communicative competence in the process of their professional training, the authors proceeded from the following provisions:

1. The formation of communicative competence as an integrative personal quality continues throughout the life of a person. However, one of the sensitive periods of 
life for its formation is the age of youth - the student years. The students are a special social category of youth, organizationally united by the institute of higher education. It has the highest educational level, social activity, a rather harmonious combination of intellectual and social maturity. So, this is favorable ground for the formation of communicative skills.

2. The formation of students' communicative competence is a multi-factor and timeconsuming process of improvement of certain skills and acquiring new ones, the development of personal qualities, the gaining of confidence and the ability to act independently in new situations. The formation of communicative competence of students includes the following aspects: interpersonal communication skills; willingness to work in a team; the ability to acquire new knowledge, using the modern educational and information technologies; the ability to use the language of the subject area correctly; contextual processing of information; the ability to receive useful scientific information from electronic libraries, abstract journals, the Internet; the ability to present their own and well-known scientific results publicly; knowledge of the basics of teaching skill.

3. The process of forming of communicative competence of students in higher educational institution includes three successive stages of their training. The first stage is organizationally motivating. It ensures the involvement of students in the educational process, focused on the formation of communication skills. At this stage, the activities of a teacher should include the group discussions, brainstorming, trainings and role-playing games, that contributes to the development of students' interest in communication, actualization of personal experience, readiness for self-expression, cooperation and interaction. The second stage is activity-developing. It is based on the involvement of students in the situations of educational and professional communication, in solving of professional problems, mastering communicative competence in the process of job training, in creation of group projects, and certain role-playing activities. The main goal of this stage is the transition from a reproductive mastery of language to a productive, creative one. The third stage is creative and professional. It is aimed at the wide involvement of students in communicative interaction, based on team work, and the organization of systematic reflexive activity of students. The result 
of this stage is the gaining of problem-professional and social experience in the application of communicative competence in various situations throughout life.

Having studied the stages of forming of communicative competence of university students, the authors summarized the criteria for the formedness of communicative competence of students. These include: motivational (interest and need for the professional communication); cognitive (mastering of the system of knowledge about the main categories and concepts of professional communication, its types and functions); the skills of effective listening and constructive conflict resolution; knowledge of the rules of professional communication; behavioral (the analysis and assessment of a professional communicative situation); the choice of communicative strategy and the formation of communicative tactics.

The result of the study of stated problem by the authors was the definition and approbation of a complex of pedagogical conditions, contributing to the successful formation of communicative competence of students at the university.

The complex of pedagogical conditions includes the following components:

The first pedagogical condition is the involvement of students in an intensive educational communicative environment, diverse in content, where the student is the subject of this environment, and the teacher contributes to this process. An intensive educational communicative environment is considered as a psychological and pedagogical reality, containing specially organized conditions for the formation of personality, as well as the opportunities for development, included in the social and spatial-objective environment. The ideas of V.V. Rubtsov and V.I. Slobodchikov were the methodological guidelines for the creation of communicative environment of the university. According to these ideas, the educational environment should have such characteristics as: intension, structuredness, variability and dynamism. An intensive educational communicative environment provides the variability of students' activities on the selection of relevant information, educational resources, the ability of students to select significant elements of the content and the corresponding interactive methods, techniques and technologies in the learning process. It should be noted, that the success of implementation of this condition depends on the following aspects: open exchange of information in the process of tasks performance and solving the problems of stimulation the initiative and responsibility of students; consideration the achievements of students in the formation of communicative competence and provision of such learning conditions in which the students feel their intellectual success and the ability to reveal their creative abilities. 
The second pedagogical condition is the creation of communicative situations on the basis of educational (professional) problems, which ensure the formation of students' communicative competence. The communicative situation is considered in the context of the idea of I.A. Kolesnikova, as a combination of specific objective and subjective factors, conditions, circumstances, relationships, in which communication takes place. In this case, the communicative situation is formed by the place, time, participants, goal, tasks, subject of communication and the content of the material. In the process of training of university students, we have developed a system of typical communicative situations, which included the situations, aimed at forming of a common culture of a future specialist; the situations, related to the future professional activities; as well as the situations, conditioned by communicative events.

The third pedagogical condition is the organization of various types of group interaction between the teacher and students, based on the application of interactive methods, techniques and technologies. The involvement of students in transformative interaction is based on the equality, activity, dialogue, teamwork, as well as on the distribution and change of roles in the process of resolving of conflict situations. Pedagogical interaction is an exchange not only of information, values, but also an exchange of activity between the teachers and students, in which the activity of one determines the activity of others, forming a professional position and model of professional behavior. Pedagogical interaction should also contribute to the development of reflection of all participants in the educational process. According to the authors, the implementation of this pedagogical condition is ensured by the use of interactive methods, techniques and technologies. It should be noted, that the interactive methods, techniques and technologies suppose the involvement of students in the active cognitive position, practical activities, interaction not only with the teacher, but also with each other, computer, interactive textbook, study guide, etc. M.V. Clarin in his works substantiates the concept of "interactive learning", considering it as a learning, based on the direct interaction of students with the learning environment, in order to gain new experience. L.K. Geykhman grounds interactive learning by communication (Geykhman, 2002). In the works of T.N. Dobrynina and N.N. Demeneva, the concept of "interactive classes" is figured, which is considered as the organizational form of educational process. According to such scientists as L.N. Vavilova, T.S. Panova and L.S. Podymova, the main features of interactive learning are the following: the interaction of students and the teacher; training, based on the experience of students, solving of real problems; active dialogue and thought activity. It should be noted, that the following characteristics are typical for interactive learning: an active position of students 
in cognitive activity; independent (individual or group) search for a solution to a problem; creation of emotional-volitional tension for vigorous activity; continuous connections between the participants in the interaction; the change of the role of a teacher as an organizer, consultant in problems solving; subject-subject relations between the participants in the interaction; reliance on the personal experience of students; organization of external interaction of students as an incentive to reflection. Interactive methods and technologies of learning (games, trainings, case methods, the analysis of situations of moral choice, problem lectures and seminars, various types of discussions, debates, round tables, the seminars on solving of professional problems, etc.) contribute to the expansion of communication in the contexts "student-student", "studentgroup", "student-audience", "student-computer", etc.

The effectiveness of the created complex of pedagogical conditions, ensuring the development of communicative competence of university students, was confirmed as a result of experimental work, carried out during 2016-2019. The experiment was attended by 194 students of 1 - 4 courses of humanitarian and technical specialties.

\section{Conclusions}

In the process of the research, we obtained the following results:

1. The content of the concept of "communicative competence of students of a higher educational institution" has been defined more exactly; its criteria and indicators have been systematized.

2. The complex of pedagogical conditions, ensuring the formation of communicative competence of university students, has been developed and experimentally tested.

3. The techniques, allowing the university teachers to develop the communicative competence of university students in the process of training, were selected, systematized and approbated.

The study of the dynamics of such personal qualities of students as communicativeness, reflection, proneness to conflict and social intelligence, allowed us to approve the hypothesis. The calculations, obtained during the experiment, confirm that the implementation of the complex of proposed pedagogical conditions contributes to the effective development of communicative competence in the process of students' professional training. 


\section{Conflict of interest}

The authors confirm that the presented data do not contain the conflict of interest.

\section{REFERENCES}

1. Ardashkin I., Martyushev N., Bezborodov V. (2015). Problem Methodology as One of the Ways of Innovative Organization of Educational Process. Procedia - Social and Behavioral Sciences, 166, 227-231. [in English].

2. Arokiasamy A., Hon Tat. H., Abdullah A. (2013). The effects of rewards system and motivation on job satisfaction: Evidence from the education industry in Malaysia. World Applied Sciences Journal, 24 (12), 1597-1604. [in English].

3. Bakholskaya N.A. (2017). The impact of interactive learning on the development of professional orientation of students of pedagogical specialties in a higher educational institution, Humanitarian and pedagogical research. - Magnitogorsk: Publishing house of Nosov Magnitogorsk State Technical University, 1(1), 45-49. [in Russian].

4. Bakholskaya N.A., Velikanova S.S., Baklykova T.Yu., Mitsan E.L., Kozhushkova N.V., Kondrashova E.N., Chernykh O.P. (2019). The impact of interactive model for university student teaching on their professional competence development, Revista Inclusiones, 6(2), 179-184. [in English].

5. Bakholskaya N.A., Velikanova S.S., Kozhushkova N.V., Sunagatullina I.I., Kashuba I.V., Chernykh O.P. (2019). Personal orientation of educational activities as a basis for the development of professional orientation of students of pedagogical specialties Religación. Revista de Ciencias Sociales y Humanidades, 4(18), 270-276. [in English].

6. Bakholskaya N.A., Velikanova S.S., Soldatchenko A.L., Kharitonova S.V., Kuvshinova I.A., Chernykh O.P. (2018). Pedagogical reflection and the ways of its development among the students of pedagogical professions, Amazonia Investiga, 7(17), 651-657. [in English].

7. Dvulichanskaya N. N. (2011). Interactive methods of training as a means of forming of key competencies, Science and Education: Electronic Scientific and Technical Edition. [in Russian].

8. Geykhman L.K. (2002). Learning to communicate in interaction: an interactive approach, Education and Science, 3, 135-146. [in Russian].

9. Goncharov, S. Z. (2004). Social competence of a person: essence, structure, criteria and significance Education and Science, 2 (2b), 3-18. [in Russian].

10. Khayrullov Zh. R. (2005). Formation of self-actualization of a person in a professional orientation, Integration of Education, 3, 156-160. [in Russian].

11. Koroleva N. M., Kosterina I. V. (2015). The role of interactive learning in modern education, Scientific notes. Electronic scientific journal of Kursk State University, 1(33). [in Russian].

12. Korthagen Fred A.J., Kessels Jos P. A. M. (1999). Linking theory and practice: changing the pedagogy of teacher education, Educ. Res, 28(4). [in English].

13. Nazarova O.L., Soldatchenko A.L., Rudakova S.V. (2018). Implementing the Continuous-and-Synergetic Approach to Social Maturity Formation in College Students, Perspectives of Science and Education, 6(36), 36-47. [in English]. 
14. Serikov V.V. (1994). Person-centered approach in education: concepts and technologies: monograph. Volgograd: Peremena, 150 p. [in Russian].

15. Shure, M. B. (1981). Social Competence as a Problem-Solving Skill, M. B. Shure, Social competence, edited by Jeri Dawn Wine \& Marti Diane Smye. - New York, London: The Guilford Press, 158 -185. [in English].

16. Soldatchenko A.L., Kostyuchenko M.V. (2017). The formation of value orientations of university students as the basis of social self-determination, Libri Magistri, 133-138. [in Russian].

17. Zimnyaya, I. A. (2003). Key competencies - a new paradigm of education result, I. A. Zimnyaya, Higher education today, 5. [in Russian].

\section{SOBRE OS AUTORES:}

\section{Olga L. Nazarova}

Prof. D. of Pedagogical Sciences, Nosov Magnitogorsk State Technical University, 38 Lenin Avenue, 455000, Chelyabinsk Region, Magnitogorsk, Russia. E-mail: info@ores.su

iD http://orcid.org/0000-0002-9616-0038

\section{Svetlana V. Rudakova}

Doctor of Philology, Professor, Nosov Magnitogorsk State Technical University, 38 Lenin Avenue, 455000, Chelyabinsk Region, Magnitogorsk, Russia. E-mail: belova-t @ ores.su

(iD http://orcid.org/0000-0002-5716-9232

\section{Tatiana V. Akasheva}

Ph.D., Nosov Magnitogorsk State Technical University, 38 Lenin Avenue, 455000, Chelyabinsk Region, Magnitogorsk, Russia. E-mail: ssv@ores.su

iD http://orcid.org/0000-0002-1449-0835

\section{Svetlana S. Velikanova}

Ph.D., Nosov Magnitogorsk State Technical University, 38 Lenin Avenue, 455000, Chelyabinsk Region, Magnitogorsk, Russia. E-mail: editor@ores.su

(iD) http://orcid.org/0000-0003-1491-464X

\section{Anastasiia A. Bakholskaia}

Ph.D. Nosov Magnitogorsk State Technical University, 38 Lenin Avenue, 455000, Chelyabinsk Region, Magnitogorsk, Russia. E-mail: a.bakholskaia2019@gmail.com

(iD http://orcid.org/0000-0001-8604-1652

\section{Oksana P. Chernykh}

Ph.D., Moscow University of Finance and Law MFUA, 17/1 Serpukhov Val str., 115191, Moscow, Russia. E-mail: p.chernykh2019@gmail.com

(iD http://orcid.org/0000-0002-2327-1319

Recebido em: 03 de novembro de 2019 Aprovado em: 24 de novembro de 2019 Publicado em: 09 de dezembro de 2019 